\title{
The Impact of EFL Teachers' Pedagogical Beliefs and Practices: Communicative Language Teaching in a Saudi University Context
}

\author{
Ahmed Alghamdi ${ }^{1}$ \\ ${ }^{1}$ English Language Institute, King Abdulaziz University, Jeddah, Saudi Arabia \\ Correspondence: Ahmed Alghamdi, English Language Institute, King Abdulaziz University, Jeddah, Saudi \\ Arabia.
}

Received: October 17, 2021

Accepted: November 25, 2021

Online Published: November 26, 2021

doi: 10.5539/elt.v14n12p171

URL: https://doi.org/10.5539/elt.v14n12p171

\begin{abstract}
This study aims to explore the pedagogical beliefs of Saudi instructors of English as a foreign language (EFL), and the extent to which they apply the values of the communicative language teaching (CLT) approach in their classroom practice. The study was conducted with 42 Saudi EFL teachers and employed a mixed methods approach. A descriptive analysis of classroom observation data was conducted. The results showed that teachers hold positive views of CLT, but that there are some discrepancies between their beliefs and their implementations of the approach. For example, most of the instructors continued to apply traditional teaching methods (i.e., grammar translation and the audio-lingual approach). The study concludes that it is essential in the Saudi EFL context for teachers to cultivate relations between their beliefs and practices to assure better language learning outcomes. The key contribution of this study lies in disclosing the reasons for the discrepancies between Saudi EFL teachers' beliefs and practices to help them develop congruence, and in highlighting the pedagogical implementations.
\end{abstract}

Keywords: beliefs, thinking, discrepancy, pedagogical, perceptions, practice

\section{Introduction}

Exploring the relationship between EFL teachers' beliefs and practices is a critical issue that has attracted the attention of many scholars (Borg, 2015; Phipps \& Borg, 2009; Tajuddin \& Alemi, 2020). Beliefs can be defined as judgments and evaluations that human beings make about themselves and others (Li, 2012). Borg (2003) also defined teachers' beliefs as "the unobservable cognitive dimension of teaching-what teachers know, believe, and think," (p. 81). Kagan (1992) described teachers' beliefs as "most of teachers' professional knowledge" and he was wondering to know what shapes teacher beliefs and practices. Furthermore, emphasizing the importance of teachers' beliefs and classroom practices particularly in language teaching and learning context, the available literature suggests that ignoring teachers' beliefs in implementing change could lead to disappointing results. To determine the relationship between teachers' beliefs and practices (Richardson and Anders, 1991) used a beliefs interview technique with 39 teachers. The results of the study demonstrated that there is a connection between these two concepts and the teacher was in the process of changing beliefs and practices. The study also demonstrated that "the changes in beliefs were preceding changes in practices" (p. 560). In other words, the findings of this study showed the relationship between teachers' beliefs and their classroom practices. Thus, due to the existence of the various types of English language methods and approaches, teachers tend to develop various beliefs towards language teaching and make their decisions based on their practice, context, personal knowledge, thoughts, and beliefs (Borg, 2003). Moreover, teachers' beliefs have a great effect upon their classroom practices, in terms of decisions they make such as teaching methods that they adopt in class or/and educational choices (Li, 2012; Pajares, 1992). Therefore, studying EFL teachers' beliefs is very important, particularly when a specific teaching approach (i.e., CLT in the current Saudi context) is being implemented in the language teaching classroom (Adil, 2020; Tudor, 2001). The following section discussed the difference between the CLT and grammar translation method or traditional approach from various perspectives.

\subsection{English in Saudi Arabia}

In the Saudi Arabian context, the Ministry's educational policy highlighted that the aim of the English language teaching primarily focused on developing EFL students' communicative competence through the implementation of CLT approach (Alhajailan, 2009 cited in Almohideb, 2019). In addition, English language is used as a 
medium of instruction, in various levels of educational institutions (Yusuf, 2017). The rationale to use CLT in Saudi context back to the importance of such approach. For instance, CLT has been widely acknowledged and welcomed as an effective language teaching approach in EFL educational settings and institutions around the world, based on a set of principles that reflect a communicative view (Richards \& Rodgers, 2001). Moreover, the use of CLT has emerged and developed to identify and meet learners' communicative needs (Richards, 2006). There is broad agreement that CLT makes the teaching and learning a good deal more inspiring, effective, and meaningful than other approaches (Tomlinson, 2003). Furthermore, in CLT teachers are encouraged to create communicative based classroom environments which combine the productive and receptive skills (Richards and Rodgers, 2014). The Saudi vision 2030, states a clear strategic plan to empower Saudi youth generation by reshaping the educational system. Improving English language teaching output at all higher education institutes is one of the goals of the current such vision (Alghamdi, 2019; Al-Mukhallafi, 2019). The importance of English proficiency is clear to many Saudis, given its prominence in the modern international business world thus there is a real and growing need for more Saudis to be proficient in both spoken and written English. In his recent study, Khan (2021) also discussed the importance of English and the role of EFL teachers in the current Saudi 2030 vision. He reported that language teaching methods should be the outcome of the well-designed modules. The following section illustrate the current study statement of the problem.

\subsection{Statement of the Problem}

As discussed above the Saudi Arabian educational policy has promoted CLT approach to develop language learners' communication skills in all higher education institutes. It should also be noted that the current Saudi educational vision 2030 highlighted the importance of English language and the role of EFL teachers to achieve the intended educational objectives (Khan 2021). However, despite to all these initiatives, as various researchers explored that language teaching practice in Saudi educational institute is still inflexible, grammar-oriented than communicative in practice and more teacher-centered approach (Alseghayer, 2014; Elyas, 2014; Khan, 2021; Tootkaboni, 2019). This in turn has a negative impact on students' language learning outcome and would spoil the attempts of the government to promote communication skills in EFL classrooms. Consequently, listening to EFL teachers' voice is crucial. Thus, this study has sought to accomplish two objectives: (a) to understand Saudi EFL teachers' application of CLT and (b) to explain the discrepancies as well as if any factors that influence the transformation of teachers' beliefs into practice with respect to the implementation of CLT at a Saudi university context.

\subsection{Significance of the Study}

The interest in conducting this study was based on the need to understand teachers' beliefs to determine the extent to which their teaching practice is supported by and applies the values of the CLT approach. In other words, the study focused to investigate the relationship between teachers' stated beliefs in terms of their responses to the questionnaire, the semi-structured interviews, and the analysis of their actual classroom practices to gain an in depth and broad information. Furthermore, the significance of this study remains to contribute concerning the Saudi EFL teaching and learning process.

\section{Literature Review}

In the Saudi Arabian context, English language is used as a medium of instruction, in various levels of educational institutions (Yusuf, 2017). Consequently, teaching English in Saudi Arabia is linked not only to the local need to prepare students in various fields (science, industry, technology, business, health, tourism), but it aims to address worldwide innovations and communications technology (Al-Mukhallafi, 2019). The Saudi higher education sectors have paid considerable attention to the English language teaching and learning process. Thus, providing the results of a standard English language test (i.e., IELTS, TOEFL) considered as a core requirement for admission and enrollment to all Saudi higher education institutes. In addition, the current Saudi Vision 2030 in education encourages undergraduate and postgraduate students to seek knowledge and becoming effective partners in the kingdom's vision (Alghamdi, 2019; Al-Mukhallafi, 2019). Another important point is that Saudi Arabia has relations with the largest oil companies around the world, and therefore English is used for most international, commercial transactions, and political negotiations (Abdallah, Al-Kahtany, \& Faruk, 2016; Alrabai, 2018; Al-Seghayer, 2014).

Numerous researchers have defined CLT in various ways. Savignon (2002 cited in Wood 2011) states that "CLT refers to both processes and goals in classroom learning" and that "the central theoretical concept in communicative language teaching is communicative competence" (p. 1). Furthermore, to advance the CLT approach and develop EFL teachers' teaching abilities, educators must have a clear definition of what CLT is. In the literature, many researchers have indicated the usefulness of CLT and its impact on language learning. CLT 
has been widely acknowledged and welcomed as an effective language teaching approach in EFL educational settings and institutions around the world, based on a set of principles that reflect a communicative view (Richards \& Rodgers, 2001). Moreover, the use of CLT has emerged and developed to identify and meet learners' communicative needs (Richards, 2006). There is broad agreement that CLT makes the teaching and learning a good deal more inspiring, effective, and meaningful than other approaches (Tomlinson, 2003).

On the other hand, the Grammar-Translation Method (GTM) or traditional method were criticized due to their extreme focus on grammatical rules and did not foster students' communicative competence. Alseghayer (2014) illustrated that the English language level achieved by students is often limited by several factors. The most influential of these is that the teaching of English is often accomplished using conventional teaching methods which rely heavily on a teacher-centered approach, with the teacher dominating the English language learning setting. Moreover, numerous researchers also argued that grammar translation method does not help students to generate language that could be used to communicate effectively in real life situations (Nunan, 2004; Richards \& Rodgers, 2001). In other words, the importance of learning a language through peer interaction in grammar translation method almost neglected. As Lindsay and Knight (2006) point out, in grammar translation, classroom activities are practised on an individual basis and group and pair work are overlooked. Similarly, this method is still predominant in the Saudi language teaching contexts due to the existence of various contextual factors such as learners' low English language proficiency, a lack appropriate environment outside the classroom for practicing English communication skills (Alharbi, 2015).

Researchers have demonstrated the importance of CLT in EFL settings and it has achieved recognition as an approach among language educators. For instance, (Larsen-Freeman \& Anderson, 2011). However, studies have shown that EFL teachers hold misconceptions in terms of understanding and applying CLT principles in their classes. Available studies found a negative correlation between EFL teachers' beliefs and their actual classroom practices due to the presence of various contextual factors. For example, teachers' teaching practices are mainly formed by their views, and mostly related to previous experiences as teachers or learners (Borg, 2015). Thus, EFL teachers frequently hold different beliefs about EFL teaching (Borg, 2003). In addition, teachers constantly resorted to their previous, teaching or learning experience, assumptions, and ideas that had an impact in their teaching behavior (Borg, 2015). Moreover, many studies reported the impact of contextual factors affecting teachers' beliefs and their practical application of CLT.

In a recent work, Farrell and Yang (2019) studied the beliefs and practices of one EAP teacher regarding to teaching second language (L2) speaking. The results did not show any differences between the teacher's stated beliefs and classroom practices. However, examples of discrepancy were noted for several other possible factors, such as to sustain the instructional flow of the class and the beginner teacher's lack of teaching experience. Thus, the researchers suggested that teachers need to observe the sources of their beliefs through systematic and consistent reflective practice to examine their beliefs and classroom practices.

In Japan, since the past three decades secondary school teachers were urged to promote students' communication skills. Nishino (2008) conducted a study to investigate 21 teachers' beliefs and practices regarding the use of CLT in their classroom. The findings obtained from the survey exposed that the participants showed a comprehensive knowledge towards the CLT principles. However, in terms of the practical part of CLT, their responses suggested that for effective use of CLT contextual factors need to be considered by policy makers. The findings revealed that number of students in class should not be increased, and teachers should be given more teaching time to apply CLT approach properly.

Another study Asif (2018) examined the perception of EFL teachers' experiences and the rationale to use the principles of CLT at a Saudi university setting. A mixed methods approach was used, and 35 participants were recruited. The results revealed that most of the participants still considered CLT quite effective and useful to be used at the university level. The findings of the interview indicated that two factors were affected teachers' implementation of CLT. These were: teachers' lack of training to use the CLT principles properly and the absence of regulations of the CLT approach and its practice.

In the Saudi EFL context, Alghanmi and Shukri (2016) conducted a case study which investigated the relationship between teachers' beliefs of grammar and grammar instruction and their instructional practices. The study employed 30 participants to complete a survey discussing their beliefs related to grammar instruction. The findings showed that the participants believe in the effectiveness of teaching grammar implicitly rather than explicitly. However, the data from classroom observation showed that there is a discrepancy between teachers' stated beliefs and classroom practice. The data from classroom observation reveal that all participants were teaching grammar explicitly than implicitly which confirmed the inconsistency between teachers' stated beliefs 
and their classroom practices. The findings also showed that six main factors (students' proficiency level, attitudes, needs, learning styles, classroom environment, and the teacher development process) were caused inconsistency between teachers' beliefs and their practices.

In a recent study, Tootkaboni (2019) examined teachers' beliefs and practices towards communicative language teaching within the EFL context of Iran. A mixed methods approach was employed, and 154 participants were recruited. The findings of the study revealed that most of the participants held a positive attitude towards CLT principles, yet the results of the study showed that there is inconsistency between teachers' expressed beliefs and their practical application of CLT. The findings also showed that the nature of examinations, large class size, teachers' low language proficiency, and lack of congruence between educational policies and realities of the teaching context were among some practical constraints which affected the teachers' stated beliefs during their classroom practices of CLT in EFL context of Iran.

Concerning the importance of investigating EFL teachers' beliefs and practical application for successful application of CLT, the current study carried out to find out any discrepancies between Saudi EFL teachers' beliefs and practical application of CLT in their classroom. To the best of my knowledge, no research has yet been undertaken on this topic using a triangulation method. The aim of this paper therefore is to fill the current gap in the literature by determining the aspects that cause inconsistencies between EFL teachers' beliefs and performance at a Saudi EFL classroom. To this end, this study attempts to provide answers to the following research questions:

\subsection{Research Questions}

The focus of this study is guided by the following two research questions.

1) What are Saudi EFL teachers' beliefs about the application of CLT?

2) Are there any discrepancies between EFL teachers' beliefs and practices with respect to CLT principles? If yes, what are the factors affecting the discrepancies?

\subsection{Theoretical Framework}

In research, it is crucial to articulate the philosophical position and paradigm underpinning the research. This has a positive effect on the quality of the research (McCallin, 2003). Guba and Lincoln (1994) also indicated that a paradigm is "the basic belief system or worldview that guides the investigator, not only in choices of method but in ontologically and epistemologically fundamental ways" (p. 105). Moreover, Bryman (2004), noted that "the nature of the research problem needs to be considered to select the correct methods in which specific data gathering tools should be employed" (p. 75). Many scholars (Brown, 2014; Larsen-Freeman, 2000) have indicated that the communicative competence $(\mathrm{CC})$ has gained a high reputation in language learning and teaching education. Thus, the study was to explore Saudi EFL instructors' pedagogical beliefs and the extent in which these instructors' classroom practices were supported by and applied CLT principles. In line with the nature of the exploratory approach, the interpretive paradigm informed the philosophical assumptions underpinning this research (Creswell \& Clark, 2018).

\section{Methodology}

\subsection{Research Design}

This study used a mixed methods research design to provide a comprehensive understanding of the research questions. In line with this, it was decided to use open and close ended question items modified from Abdelkader's (2019) study. In addition, the researcher utilized two more instruments, semi-structured interviews, and classroom observation checklist to ensure the consistency and validity of the results (Creswell \& Clark, 2018). To ensure the validity of the questionnaire, the first draft of the questionnaire was given to a sample consisting of three assistant professors and two experienced EFL instructors. Considering their comments and suggestions, minor changes were made in the piloted questionnaire to enhance content validity.

\subsection{Participants}

The context in which the data for this study were collected is at the English language Institute (ELI) in a Saudi Arabian University. Table 1 shows the demographic information of the participants, students' language level, number of classes observed, and total duration of observation (minutes). The teachers were assigned codes ( $\mathrm{T} 1$, $\mathrm{T} 2, \mathrm{~T} 3$, and $\mathrm{T} 4)$ to preserve their anonymity. 
Table 1. Participants' demographic information, students' language level, and classroom observation.

\begin{tabular}{llllll}
\hline Teacher & $\begin{array}{l}\text { Teaching } \\
\text { experience }\end{array}$ & Educational qualification & $\begin{array}{l}\text { Students' } \\
\text { language level }\end{array}$ & $\begin{array}{l}\text { Classes } \\
\text { observed }\end{array}$ & $\begin{array}{l}\text { Time observed } \\
\text { (min) }\end{array}$ \\
\hline T1 & 12 years & MA in English & A2 & 4 classes & 360 \\
T2 & 6 years & MA in TESOL & A2 & 4 classes & 360 \\
T3 & 9 years & MA in Education & A2 & 4 classes & 360 \\
T4 & 14 years & MA in Applied Linguistics & A2 & 4 classes & 360 \\
& & & & & $\mathbf{1 , 4 4 0}$ \\
\hline
\end{tabular}

\subsection{Data Collection Method}

The aim of using the questionnaire stemming from various aspects of the CLT principles informs EFL teachers' comprehensive perspective regarding such approach. A general outline of the data collection procedure in this study includes the following steps. First, a sample of 42 EFL teachers responded to the questionnaire which comprised nine statements organized under four themes examining the EFL teachers' beliefs regarding the principles of CLT. Second, $10 \%$ of the total participants 4 teachers were agreed to be observed. The items from the questionnaire were modified to be used as a checklist for classroom observation. The themes appeared to focus on the following aspects: (a) language teaching and learning activities (b) error correction (c) teaching grammar and (d) the role of the teacher. Similarly, the researcher used semi-structured interviews and interviews' questions were determined to meet up with the study's research questions (Dornyei, 2007:136).

\subsection{Data Analysis}

At the final stage, the data obtained from the teachers' questionnaire were analyzed statistically. The findings of classroom observation are described in the order in which they were coded according to the modified checklist. The thematic analysis developing from the transcribed interviews were used to analysis the interviews data. This in turn, allowed the researcher to triangulate the participants responses concerning the research questions. All the It should also be noted that all ethical consideration was fulfilled and the permission from vice-dean for scientific research was obtained to conduct the current study. Participants were required to sign a consent form before they join the study. All the interviews were conducted in English as the participants hold an advanced degree in language teaching and experienced EFL teachers.

\section{Results}

\subsection{Teachers' Beliefs about Communicative Language Teaching}

The teachers' responses to the questionnaire and their classroom practices were investigated and discussed according to the research questions. First, the participants were asked to indicate the extent of their agreement with the principles of CLT on a four-point scale $(1=$ strongly agree, $2=$ agree, $3=$ disagree, $4=$ strongly disagree). Figure 1 shows EFL teachers' beliefs concerning CLT principles.

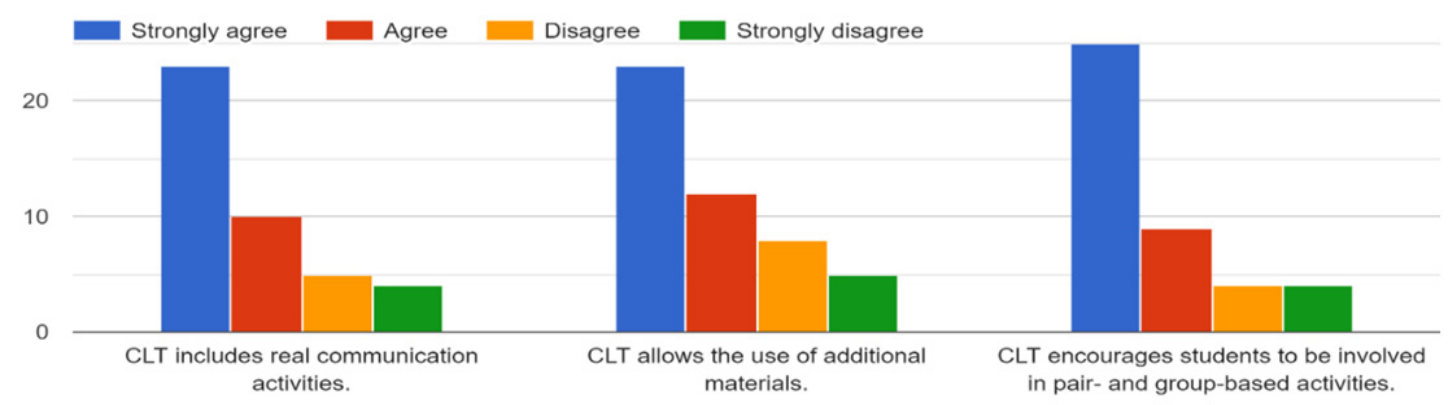

Figure 1. Language teaching and learning activities

Regarding instructors' language teaching and learning activities Figure 1 illustrates that many of the participants (33 with percentage $78.5 \%$ ) stated "strongly agreed and agree" that CLT includes real communication activities to encourage language learning, with only (9 with percentage $21.4 . \%)$ stated "disagree and strongly disagree". About the statement whether CLT allows the use of additional materials or not. Most of the participants ( 35 with percentage $83.2 \%$ ) stated "strongly agree and agree" that CLT allows the use of additional materials in class besides the coursebook against (12 with percentage 28.5\%) selecting "disagree and strongly disagree". Furthermore, the vast majority (34 with percentage $80.9 \%$ ) of the participants believed that CLT encourages 
students to be involved in pair- and group-based activities. Only ( 8 with percentage 19\%) stated disagree and strongly disagree with the statement.

The results from the interviews revealed that the instructors predominantly understood that the use of activities improved students' involvement to the language learning process. Teachers were asked to explain the following question, Q1. How is it important to use pair and group work in your teaching practice? T3 said

"In order to motivate my students, I usually apply different activities within the given period. I believe that using pair- and group-based activities is extremely interesting more beneficial and fostering students' communication skills".

With regard the use of authentic materials $\mathrm{T} 2$ explained some of the obstacles that prevented him from the use of such materials: "If I have had more time in class, I would have used authentic materials with the current course book to enhance learners' language learning process

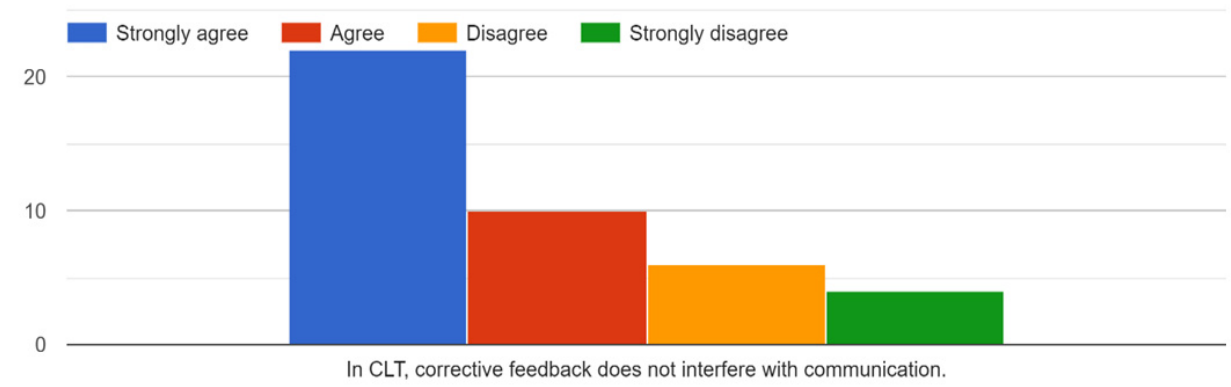

Figure 2. Error correction in CLT

In this study, (32 with percentage $76.1 \%$ ) of the participants believed that corrective feedback in CLT needs to be implicit and should not interfere with communication, while (10 with percentage $23.9 \%$ ) of the participants were of the view that errors need to be corrected explicitly. These participants stated that errors are not allowed at any time in their classrooms. They also believed that teachers should provide oral and written corrective feedback immediately. During the post-observation interviews teachers were asked to explain Q2. To what extent do they correct students' errors? T4 was explained the way he preferred to correct his students' errors in class, stating:

"I would write all the errors on the board and let learners correct them immediately, because this practice helps learners amend their errors. Therefore, I believe that errors should not be ignored."

Similarly, T3 reported

"I believe that correcting learners' errors should take place immediately because if teachers let it pass to learner's conscious and use of language, it will be difficult to correct them in the future."

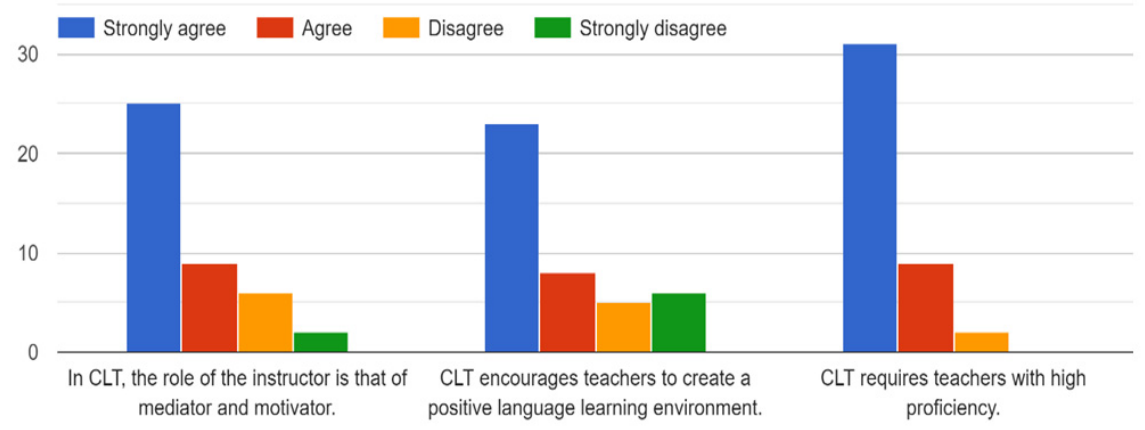

Figure 3. The role of the teacher

The third figure shows EFL teachers' beliefs regarding the role of the teacher in CLT. Most of the teachers showed positive beliefs concerning the three statements in this category. For instance, ( 34 with percentage $80.9 \%$ ) of the participants responded "strongly agree and agree" to the role of the teacher in CLT being that of a mediator, Likewise, (31 with percentage $73.7 \%$ ) believed that CLT encourages teachers to create a positive language learning environment. Finally, (40 with percentage $95.2 \%$ ) of the participants responded "strongly 
agree and agree" to teachers requiring a high level of proficiency to CLT in their classroom. However, there were those who disagreed or strongly disagreed, and the post-observation interview data revealed several factors influencing the teachers' misreading of the communicative approach. However, it was noted also that as far as CLT encourage the students centered approach, several teachers believed that would reduce their power in terms of the classroom management process as well as controlling students' behaviors in such classes. Teachers explained that their responsibilities in the classroom, as T3 stated that: "I think at the current classroom situation, having 35 students in one language class, teachers should have more power to manage students' behaviors than just being facilitators and letting students decide what they want to learn".

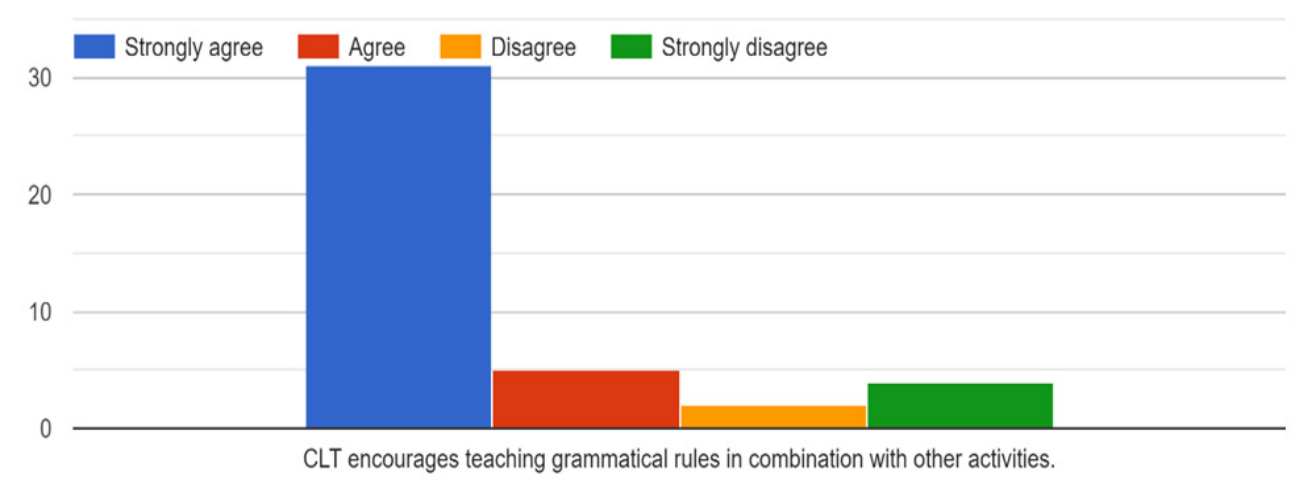

Figure 4. Grammar in Communicative Language Teaching

As shown in Figure 4, many of the participants (36 with percentage $85.8 \%$ ) of the participants showed positive attitude regarding CLT encouraging teaching grammatical rules in combination with other activities. However, (6 with percentage 14.2\%) of the teachers responded, "disagree and strongly disagree." Several gave reasons for believing that grammar should be taught explicitly and in one case, traditional methods was highlighted over the communicative approach and the teacher used learners' native language to converted some of grammar rules and complex vocabularies.

\subsection{EFL Teachers' Classroom Practice}

Table 2 presents the results for the teachers' classroom practice, which are then discussed according to the themes and the data obtained from the classroom observation. This section mainly response the second research question of this study. Highlighting teachers' classroom practices and discussing if any discrepancies that occurred during the application of CLT in their classroom.

Table 2. EFL teachers' practice of CLT in the classroom

\begin{tabular}{|c|c|c|c|c|c|}
\hline Themes & Practices & T1 & T2 & T3 & $\mathrm{T} 4$ \\
\hline \multirow{3}{*}{$\begin{array}{l}\text { Language teaching } \\
\text { methods }\end{array}$} & $\begin{array}{l}\text { Communicative-based approach was implemented } \\
\text { through written and oral activities }\end{array}$ & $\checkmark$ & $\checkmark$ & $\checkmark$ & - \\
\hline & $\begin{array}{l}\text { Additional authentic materials were used alongside } \\
\text { the coursebook }\end{array}$ & - & - & $\checkmark$ & - \\
\hline & Group-based activities are highly encouraged in class & $\checkmark$ & $\checkmark$ & $\checkmark$ & $\checkmark$ \\
\hline Error correction & Positive verbal and written feedback were provided & $\checkmark$ & $\checkmark$ & $\checkmark$ & $\checkmark$ \\
\hline \multirow{2}{*}{$\begin{array}{l}\text { Teaching } \\
\text { grammar }\end{array}$} & $\begin{array}{l}\text { Grammar was explained in combination with other } \\
\text { activities }\end{array}$ & $\checkmark$ & - & $\checkmark$ & - \\
\hline & $\begin{array}{l}\text { The teaching process mostly encouraged } \\
\text { grammar-based activities }\end{array}$ & $\checkmark$ & $\checkmark$ & - & $\checkmark$ \\
\hline \multirow{3}{*}{$\begin{array}{l}\text { The role of the } \\
\text { teacher }\end{array}$} & Teachers' role was in line with CLT principles & $\checkmark$ & $\checkmark$ & $\checkmark$ & - \\
\hline & $\begin{array}{l}\text { Classroom interaction mainly got place between } \\
\text { teacher and students }\end{array}$ & $\checkmark$ & $\checkmark$ & $\checkmark$ & $\checkmark$ \\
\hline & $\begin{array}{l}\text { Teachers showed high English language proficiency } \\
\text { in class }\end{array}$ & $\checkmark$ & $\checkmark$ & $\checkmark$ & - \\
\hline
\end{tabular}




\subsection{Language Teaching Methods}

In this section the researchers describe the four EFL teachers' classroom practices to determine in which their practices were supported by and applied CLT principles in the university context. Although the participants had the same level of qualification, all had more than five years' EFL teaching experience, and were teaching students at the same level (A2) (see Table 1), the classroom observation revealed differences between their expressed beliefs and their classroom practice. In each lesson the four participants were observed to demonstrate who among them preferred a traditional approach and who adopted a CLT approach according to the themes of the study. The findings revealed that three out of the four teachers (T1, T2, and T3) used a communicative approach, employing written and oral activities. These teachers were clearly convinced of the value of including a communicative-based approach in their teaching. In contrast, one of the participants (T2), although showing some understanding of the communicative approach, did not apply it within the actual teaching classroom; rather, he used grammar-based teaching in preference to CLT. During the post-observation interview, T2 explained that he believed: "Traditional teaching - actually grammar-based teaching, but with an emphasis on the learners' language proficiency — will help them to understand what they need to pass the course."

The use of authentic materials in class was also observed, but only by one teacher, who integrated additional materials alongside the coursebook. He was properly organized in each class in terms of planning all the resources needed in advance. He was also very determined to co-operate with his students. In contrast, the other three teachers were not inclined to use additional authentic materials. Explaining this, the group of teachers (T1, T2, and T4) reported: Using additional authentic materials in the language classroom is a great idea, but due to the limited teaching time we focus on the students' coursebook because it covers the core language skills, and it is a good source of oral and written exam preparation.

The observation also focused on the effectiveness of classroom activities in terms of delivering the learners' needs in the English language courses. Although in each class teachers were observed to apply either pair-or group-based activities, they mostly highlighted grammar-rules rather than improving the students' interaction skills. Nonetheless a couple of the teachers (T3 and T4) did put some effort into involving the students within group-based activities, and during the interviews stated that: "We suggest that the use of classroom activities need to be increased, which in turn will encourage learners to be exposed to the target language."

Throughout the four observed classes, the EFL teachers demonstrated behavior reflecting their positive beliefs about the error correction process. Moreover, during the interviews, the participants also stated the importance of providing useful feedback in the language learning process. Therefore, corrective feedback was highlighted in all the classes. However, the teachers varied in terms of the types of feedback they gave. For instance, it was observed that $\mathrm{T} 1$ used a positive corrective feedback technique, providing correction implicitly with examples and not using a direct error correction strategy. The students were allowed to present possible corrections of their errors. However, if they could not do so, the teacher would provide corrective feedback immediately. In contrast, T3 and T4 were observed mostly to rush to expose learners' errors and provide feedback explicitly. When they were asked to explain their feedback strategy, T3stated that: "I believe that learners' inaccuracies need to be corrected instantly, otherwise a student might face challenges when he later on uses the language."

In the questionnaire, although $85 \%$ of the teachers responded that CLT encourages grammar teaching in combination with other activities. However, in actual classroom practices, the grammatical procedures were highlighted and exercised more than the communicative approach in most classes observed and the teacher translated the grammar rules into the learners' first language. The participants explained their reasons for emphasizing traditional methods over the CLT approach and their responses can be summarized as follows: We believe that grammar is essential in language learning. However, due to the learners' low English proficiency, teachers focus on memorizing and drilling grammar rules. In addition, because of the grammar-based exam procedures in this context, we try our best to help students pass their exams (T2 and T4).

Regarding the role of the EFL teachers in class and relevance to the principles of CLT, the findings reveal that some teachers were able to apply some of the key principles, but others misunderstood aspects of the approach, presuming that CLT cannot be combined with grammar teaching. It was observed that some teachers were organized and used CLT approach to engage learners in practical use of language. However, in other classes group work and other practices, such as opinion sharing and knowledge gap activities, were not used properly in the classroom. The findings obtained from post-observation interviews revealed that some Saudi EFL instructors showed positive beliefs concerning the application of CLT. However, classroom observation data revealed that traditional teaching methods were thought overtly, rather than merging them with the main CLT. This in turn, was a dominant obstacle that inhibited CLT activities in the observed classes. One of the teachers was asked to explain 
the inconsistencies between their beliefs and practices regarding the implementation of CLT principles in their EFL classes and $\mathrm{T} 3$ articulated as follows:

Numerous language learning opportunities can be offered using the CLT approach rather than grammar translation or traditional methods. I do also believe that CLT emphasizes improving students' communication skills. Nevertheless, there are many challenges that prevent teachers from using CLT that need to be considered. For instance, having large number of students, implementing restricted instruction upon teachers to finalize the assigned units or chapter regardless of learners' language learning comprehensions progress.

\section{Discussion}

The data presented above explained that there are discrepancies between the participants in their views of the implementation of CLT principles. In this study, the results of the analysis of the various sources of data highlight the value of interpretive studies drawing on a descriptive understanding of what language teachers do in EFL classrooms, specifically based on the participants' explanations of their beliefs and classroom practices in relation to the application of CLT principles. The data obtained from the semi-structured interviews suggested that teachers' beliefs were influenced by numerous contextual factors that affected the transformation of their beliefs into practice during the implementation of CLT in their classroom.

The first difference concerned EFL teachers' beliefs and practice about the application of CLT principles. The study explains that while some teachers were used CLT principles, in terms of applying ccommunicative-based approach through written and oral activities. Whereas, others apply the traditional based approach, believing that teaching grammar-rules cannot be combined with CLT. According to the data obtained from classroom observation that only one teacher misunderstanding some CLT features. However, he justified that providing the traditional teaching approach in class was based on students' language proficiency and he believed that this approach would help students to understand what they need to pass the course rather than fostering their communication skills. This view was shared by Tootkaboni (2019) who reported that that lack of congruence between educational policies and realities of the teaching context often affected teachers' beliefs when it comes to the practical application of CLT principles.

The second differences between the participants concerned the use of additional authentic materials alongside the coursebook. The findings showed that teachers held various beliefs regarding the use of additional authentic materials alongside the coursebook, despite holding similar qualifications and having been engaged in EFL teaching for numerous years. Nevertheless, during the observation, only one teacher used additional materials alongside the coursebook. Thus, it was apparent that while teachers may express an understanding of the value of using authentic materials, they may prefer a traditional approach, rather than adopting the CLT principles. Teachers justified their reasons due to the limited teaching time that they need to focus on the students' coursebook, and it is a good source of oral and written exam preparation.

The third difference in the participants' practical application of CLT concerned the way teachers providing corrective feedback. Although results demonstrated participants' positive attitudes to corrective feedback, which they considered to be the most effective teaching tool enhancing the language learning process. However, the teachers differed in how they provided feedback, T1 using direct explicit feedback and T3 using more implicit ways. In terms of their reasons, beyond providing such feedback either in oral or written form, T1 saw an immediate need to amend students' errors, if they might face challenges using the language if their errors had not been corrected explicitly, while T3 argued that students' errors needed to be corrected implicitly so as not to interfere with communication. Again, the results of this study agree with findings of Borg (2003, p. 39), who stated that teachers' beliefs and practices are predominantly shaped by their experience and previous learning styles. However, with regard the use of group-based activities, the findings releveled that all teachers applied group-based activities and students were highly encouraged in class.

The fourth difference found in this study between the participants concerned explaining grammar in combination with other activities. Although (T2 and T4) reported that they bused traditional and communicative based teaching approach, their actual practices were deeply focused on grammatical rules. The classroom activities were mainly dominated by teachers, providing students insufficient classroom interaction time in terms of answering only short requests. These teachers supported their reasons due to their own beliefs that grammar is essential in language learning, and they focus on memorizing and drilling grammar rules because of the grammar-based exam procedures in this context. In addition, teachers justified their application of grammar-based methods because they believed that they are trying their best to help students pass their exams. This finding comes in line with Nishino (2008) who reported that for effective use of CLT some contextual factors first need to be considered by 
educational policy makers. In the current study context, exam-oriented approach found to be the main factors behind the use of traditional methods. This view was also shared by Al-Seghayer (2014) who reported that the English language level achieved by Saudi students is often limited by several factors. The most influential of these is that the teaching of English is often accomplished using conventional teaching methods.

The fifth and last difference found in this study between the participants concerned particularly utilizing grammar-based methods over CLT in their classes, the participants mentioned various external and internal factors that they encountered in the EFL context. For instance, many of the textbook activities were structured in line with grammar-based learning and the assessments predominantly focused on grammatical rules. In the teachers' practice, what was consistent were their views of classroom interaction, and communication between them and their students. Three out of the four teachers had developed positive interactions with the learners, rather than keeping the typical student-teacher relationship. Two of the participants were constantly provide chances for their students encouraging them to participate within their interest topics and issues. This contrasted with the prevalent emphasis on the importance of using a grammar-based approach rather than focusing on communicative aspects. Furthermore, the participants described the difficulties they experienced about the application of CLT in their classes. These problems are referred to several factors. For example, lack of professional development programs focused on language teaching and learning issues, their learners' low language proficiency, and institutional policies related to the centralized educational system. This view was shared by Alghanmi and Shukri (2016) who reported that six main factors (students' proficiency level, attitudes, needs, learning styles, classroom environment, and the teacher development process) were caused inconsistency between teachers' beliefs and their practices.

\section{Conclusion}

The current study sought to investigate EFL teachers' pedagogical beliefs and their classroom practices during the application the CLT approach. The focus was on illustrating EFL teachers' understanding of such approach and to find out if any differences had taken place between their stated beliefs and the classroom practices. The post-observation interviews conducted with participants focused on various themes. The findings showed that despite the Saudi EFL teachers' positive beliefs about the value of CLT, in agreement with other studies (e.g., Abdulkader, 2016; Al Seghayer, 2014), too many were inclined to rely on traditional teaching techniques, such as rote memorization, translation, and drilling. Moreover, the teachers tended to attribute problematic issues to several internal and external factors. The study shows that there are various challenges resulting in difficulties for teachers in applying CLT principles in the EFL classroom. These challenges include, for instance, learners' low proficiency, large size classes, limited teaching hours, and a packed syllabus, which needs to be covered within a given period. Indeed, all the participants agreed that these factors together create challenges for language teachers and prevent them from applying a communicative-based teaching approach.

In terms of the implications of the study, if the language institute wanted to improve the application of CLT in a Saudi EFL context, decision makers need to reconsider the following core issues carefully. For instance, the large number of students in a particular class needs to be decreased, because there is an association between class size and learning, whereby learners in larger classes experience less effective learning. Teachers' overworked teaching hours should also be reduced so classroom activities could be applied successfully. In-service training should be provided, because some of the difficulties inherent in the current program arise from the fact that teachers are not adequately trained. Professional training focusing on CLT methods should be viewed both as urgent for the language teachers and a requirement for improving the current program. Saudi researchers also need to conduct further studies to explore further research using a larger sample of participants for generalization.

The limitation of the study concerns the selection and participation of only male teachers. According to the Saudi Arabian educational regulations at the university's accessibility to the female section of the university was complicated. Having a greater number of both female and male participates in the study would have led to a richer set of data in terms of determining beliefs and classroom practices linked to the application of CLT in a university context, an area which still needs further development. Similarly, there were issues with access to teaching staff for further interviews due to their overloaded teaching hours.

\section{References}

Abdallah, H., Al-Kahtany, A., \& Faruk, G. (2016). English as the Medium of Instruction in Saudi Higher Education: Necessity or Hegemony? Journal of Language Teaching and Research, 7(1), 49-58. https://doi.org/10.17507/jltr.0701.06 
Abdulkader, F. (2016). An investigation of Saudi EFL teachers' perceptions of the appropriateness of Communicative Language Teaching (CLT) in a Saudi Context. International Journal of Educational Investigations, 3(6), 42-68.

Abdulkader, F. (2019). Exploring Saudi EFL Teachers' and Learners' Perceptions Regarding the Application of Communicative Language Teaching (CLT) in the English Language Classroom. Unpublished $\mathrm{PhD}$ thesis. University of Northumbria.

Adil, M. (2020). Exploring the Role of Translation in Communicative Language Teaching or the Communicative Approach. Sage Open, 10(2). https://doi.org/10.1177/2158244020924403

Alghamdi, A. (2019). Exploring English Language Needs: Business Students' and Teachers' Perspectives in a Saudi Undergraduate Context. Special Issue 1: Application of Global ELT Practices in Saudi Arabia, 4-17. https://doi.org/10.24093/awej/elt1.1

Alghanmi, B., \& Shukri, N. (2016). The Relationship between Teachers' Beliefs of Grammar Instruction and Classroom Practices in the Saudi Context. English Language Teaching, 9(7). https://doi.org/10.5539/elt.v9n7p70

Alharbi, H. A. (2015). Improving Students' English-Speaking Proficiency in Saudi Public Schools. International Journal of Instruction January, 8(1). https://doi.org/10.12973/iji.2015.818a

Alhejailan, T. (2009). Tareekh Ta'aleem Al-lughah Al-Englizyah.

Almohideb, N. A. (2019). Investigating Saudi Arabian Teachers' and Students' Perspectives on Teaching English by Using the CLT Approach. A Thesis Submitted in Fulfilment of the Requirements for the Degree of Doctor of Philosophy (PhD).

Al-Mukhallafi, T. R. (2019). English in Saudi Arabia: Status and Challenges in The Light of Prince Mohammad bin Salman's Vision 2030. International Journal of English Linguistics, 9(4). https://doi.org/10.5539/ijel.v9n4p209

Alrabai, F. (2018). Learning English in Saudi Arabia. In book: English as a Foreign Language in Saudi Arabia: New Insights into Teaching and Learning English (pp. 102-119). Publisher: Routledge. https://doi.org/10.4324/9781315688466-5

Al-Seghayer, K. (2014). The Actuality, Inefficiency, and Needs of EFL Teacher-Preparation Programs in Saudi Arabia. International Journal of Applied Linguistics and English Literature, 3(1). https://doi.org/10.7575/aiac.ijalel.v.3n.1p.143

Asif, F. (2018). Teachers' Perceptions of the Communicative Language Approach at a Saudi University. International Journal of English Language Education, 6(1). https://doi.org/10.5296/ijele.v6i1.12579

Borg, S. (2003). Teacher cognition in language teaching: A review of research on what language teachers think, know, believe, and do. Language Teaching, 36(2). https://doi.org/10.1017/S0261444803001903

Borg, S. (2015). Teacher Cognition and Language Education: Research and Practice. London: Continuum.

Brown, J. D. (2014). Principles of Language Learning and Teaching (5th ed.). Cambridge, UK: Cambridge University Press.

Bryman, A. (2004). Integrating quantitative and qualitative research: how is it done? Qualitative Research, 6(1), 97-113. https://doi.org/10.1177/1468794106058877

Creswell, J. W., \& Plano Clark, V. L. (2018). Designing and Conducting Mixed Methods Research (3rd ed.). Sage.

Elyas, T. (2014). Learning English in Saudi Arabia: A Socio- Cultural perspective. International Journal of English Language and Linguistics Research, 2(3), 56-78.

Farrell, T., \& Yang, T. (2019). Exploring an EAP Teacher's Beliefs and Practices in Teaching L2 Speaking: A Case Study. RELC Journal, 50(1), 104-117. https://doi.org/10.1177/0033688217730144

Guba, E. G., \& Lincoln, Y. S. (1994). Competing Paradigms in Qualitative Research. In Denzin, N. K. \& Lincoln, Y. S. (Eds.), Handbook of Qualitative Research (pp. 105-117). Thousand Oaks: Sage Publications.

Kagan, D. M. (1992). Professional Growth among Pre-Service and Beginning Teachers. Review of Educational Research, 62(2), 129-169. https://doi.org/10.3102/00346543062002129 
Khader, F. R. (2012). Teachers' Pedagogical Beliefs and Actual Classroom Practices in Social Studies Instruction. American International Journal of Contemporary Research, 2(1), 73-92.

Khan, I. A. (2021). The Importance of English Language and Role of Teachers in Implementation of Saudi Vision-2030. JKAU/ Arts and Humanities, 29, 739-756. https://doi.org/10.4197/Art.29-4.27

Larsen-Freeman, D. (2000). Techniques and principles in language teaching (2nd ed.). New York: Oxford University Press.

Larsen-Freeman, D., \& Anderson, M. (2011). Techniques and Principles in Language Teaching (3rd ed.). New York: Oxford University Press.

Li, X. (2012). The Role of Teachers' Beliefs in the Language Teaching-Learning Process. Theory and Practice in Language Studies, 2(7), 1397-1402. https://doi.org/10.4304/tpls.2.7.1397-1402

Lindsay, C., \& Knight, P. (2006). Learning and teaching English. Oxford: Oxford University Press.

McCallin, A. M. (2003). Designing a grounded theory study: some practicalities. Nursing in Critical care, 8(5), 203-208. https://doi.org/10.1046/j.1362-1017.2003.00033.x

Nishino, T. (2008). Japanese Secondary School Teachers' Beliefs and Practices Regarding Communicative Language Teaching: An Exploratory Survey. JALT Journal, 30(1). https://doi.org/10.37546/JALTJJ30.1-2

Nunan, D. (2004). Task-Based Language Teaching. Cambridge: Cambridge University press. https://doi.org/10.1017/CBO9780511667336

Pajares, M. F. (1992). Teachers' Beliefs and Educational Research: Cleaning Up a Messy Construct. Review of Educational Research, 62(3), 307-332. https://doi.org/10.3102/00346543062003307

Phipps, S., \& Borg, S. (2009). Exploring tensions between teachers' grammar teaching beliefs and practices. System, 37(3), 380-390. https://doi.org/10.1016/j.system.2009.03.002

Richards, J. C. (2006). Communicative language teaching today. New York: Cambridge University Press.

Richards, J. C., \& Rodgers, T. S. (2001). Approaches and methods in language teaching (2nd ed.). New York: Cambridge University Press. https://doi.org/10.1017/CBO9780511667305

Richards, J. C., \& Rodgers, T. S. (2014). Approaches and Methods in Language Teaching (3rd ed.). New York: Cambridge University Press.

Richardson, V., \& Anders, P. (1991). The Relationship Between Teachers' Beliefs and Practices in Reading Comprehension Instruction. American Educational Research Journal, 28(3), 559-586. https://doi.org/10.3102/00028312028003559

Savignon, S. (2002). Interpreting communicative language teaching. New Haven: Yale University Press.

Tajeddin, Z., \& Alemi, M. (2020). Pragmatics Pedagogy in English as an International Language (1st ed.). London, Routledge. https://doi.org/10.4324/9781003097303-1

Tomlinson, B. (2003). Developing Materials for Language Teaching. London: Continuum.

Tootkaboni, A. A. (2019). Teachers' beliefs and practices towards communicative language teaching in the expanding circle. Revista signos, 52(100). https://doi.org/10.4067/S0718-09342019000200265

Tudor, L. (2001). The Dynamics of the Language Classroom. Cambridge: Cambridge University Press.

Wood, J. (2011). Communicative Language Teaching (CLT) and communication strategies (CSs): Theory and practice.

Yusuf, N. (2017). Changes Required in Saudi Universities Curriculum to Meet the Demands of 2030 Vision. International Journal of Economics and Finance, 9(9), 111-116. https://doi.org/10.5539/ijef.v9n9p111

\section{Copyrights}

Copyright for this article is retained by the author(s), with first publication rights granted to the journal.

This is an open-access article distributed under the terms and conditions of the Creative Commons Attribution license (http://creativecommons.org/licenses/by/4.0/). 